\title{
Propagation of Asian isolates of canine distemper virus (CDV) in
} hamster cell lines

\author{
Serageldeen Sultan ${ }^{1}$, Nguyen Thi Lan ${ }^{2,3}$, Toshiki Ueda², Ryoji Yamaguchi², \\ Ken Maeda ${ }^{1}$ and Kazushige Kai*1
}

Address: ${ }^{1}$ Department of Veterinary Microbiology, Faculty of Agriculture, Yamaguchi University, Yamaguchi 753-8515, Japan, ${ }^{2}$ Department of Veterinary Pathology, Faculty of Agriculture, University of Miyazaki, Miyazaki 889-2192, Japan and ${ }^{3}$ Department of Veterinary Pathology, Faculty of Veterinary Medicine, Hanoi University of Agriculture, Trau Quy-Gia Lam-Ha Noi, Vietnam

Email: Serageldeen Sultan - seaas@lycos.com; Nguyen Thi Lan - 0d402u@cc.miyazaki-u.ac.jp; Toshiki Ueda - 0d402u@cc.miyazaki-u.ac.jp; Ryoji Yamaguchi - 0d402u@cc.miyazaki-u.ac.jp; Ken Maeda - kmaeda@yamaguchi-u.ac.jp; Kazushige Kai* - kzkai@yamaguchi-u.ac.jp

* Corresponding author

Published: 16 October 2009

Acta Veterinaria Scandinavica 2009, 5 I:38 doi:10.1 I86/I75I-0I47-5I-38

Acta Veterinaria Scandinavica 2009, 51.38 doi. $10.1186 / 1751-0147-51-38$

(C) 2009 Sultan et al; licensee BioMed Central Ltd.

This is an Open Access article distributed under the terms of the Creative Commons Attribution License (http://creativecommons.org/licenses/by/2.0), which permits unrestricted use, distribution, and reproduction in any medium, provided the original work is properly cited.
Received: 6 July 2009

Accepted: 16 October 2009

\begin{abstract}
Backgrounds: The aim of this study was to confirm the propagation of various canine distemper viruses (CDV) in hamster cell lines of HmLu and BHK, since only a little is known about the possibility of propagation of CDV in rodent cells irrespective of their epidemiological importance.

Methods: The growth of CDV in hamster cell lines was monitored by titration using Vero.dogSLAMtag (Vero-DST) cells that had been proven to be susceptible to almost all field isolates of CDV, with the preparations of cell-free and cell-associated virus from the cultures infected with recent Asian isolates of CDV (I3 strains) and by observing the development of cytopathic effect (CPE) in infected cultures of hamster cell lines.

Results: Eleven of 13 strains grew in HmLu cells, and 12 of 13 strains grew in BHK cells with apparent CPE of cell fusion in the late stage of infection. Two strains and a strain of Asia I group could not grow in HmLu cells and BHK cells, respectively.

Conclusion: The present study demonstrates at the first time that hamster cell lines can propagate the majority of Asian field isolates of CDV. The usage of two hamster cell lines suggested to be useful to characterize the field isolates biologically.
\end{abstract}

\section{Background}

Canine distemper virus (CDV) is a negative-strand RNA virus that belongs to the genus Morbillivirus in the family Paramyxoviridae. The CDV induce distemper in dogs, raccoons [1] and ferrets [2]. Outbreaks of distemper in seals on Lake Baikal [3], in leopards and other feline animals in zoos [4], and in lions in the Serengeti National Park [5], indicate additional animal hosts other than the generally accepted hosts.
CDV has been isolated by a few cell lines other than the cells derived from dog as follows. Vero [6] and B95a B-cell line [7] were derived from monkey, and MV1Lu lung cells were derived from mink [8]. Recently, the gene of dog signaling lymphocyte activation molecule (also known as dog SLAM or CD150) [9], was introduced into Vero cells and Vero.dogSLAMtag (Vero-DST) cells were established [10]. By Vero-DST cells, various field strains were isolated [10-12]. Thus there are only a few cell lines derived from other than generally accepted hosts. 
During a study on the molecular characterization of the hemagglutinin $(\mathrm{H})$ and fusion $(\mathrm{F})$ protein genes using mouse retrovirus vectors, the hamster HmLu cell line was suggested to be susceptible to CDV infection. Hamsters are not generally accepted hosts and there is little knowledge of the propagation of CDV in rodent cells.

\section{Methods \\ Cells and Viruses}

Vero-DST cells were established as described above [10]. HmLu cells were derived from hamster lung cells [13]. BHK cells were derived from baby hamster kidney cells [14]. All cells were passaged and maintained in Dulbecco's modified Eagle's medium (D-MEM; autoclavable; Nissui Pharmaceutical Co. Ltd., Tokyo, Japan) supplemented with $10 \%$ fetal bovine serum in a $\mathrm{CO}_{2}$ incubator at $37^{\circ} \mathrm{C}$.

Thirteen strains of CDV were isolated and propagated, one or a few times, in Vero-DST cells and stored at $-80^{\circ} \mathrm{C}$ until use. Specimens were collected from diseased dogs in Japan except for strain Th12, which was sampled in Thailand. Nine strains were newly isolated except for strains of 007 Lm, 009L, 011C [11], and Ac96I [12]. The phylogenetic relationship of nine new strains were determined by the sequencing of their $(\mathrm{H})$ genes [15] where strains 55L, M25CR, 50Con and 50Cbl were assigned as members of Asia 2 group, while strains Th12, 50Sc, 81ND, 82Con and $83 \mathrm{mLN}$ were assigned as members of Asia 1 group. The vaccine strain of Onderstepoort (Ond) was used as a control.

\section{Virus titration}

Vero-DST cells were seeded on 24-well multi-plates (Sumitomo-Bakelite, Tokyo, Japan) at a concentration of $1 \times$ $10^{5}$ cells per well and incubated overnight. After the removal of media, the cultures were overlaid with $0.1 \mathrm{ml}$ of each serial 10-fold-diluted virus suspensions in duplicate manner, and incubated for $1 \mathrm{~h}$ with rocking at 15min intervals. After virus adsorption, the suspensions were removed by suction and the cultures were washed once with culture media. The cultures were then overlaid with medium $(1 \mathrm{ml})$ containing $1 \%$ methyl cellulose4,000 (Nacalai Tesque, Kyoto, Japan; methyl cellulose media), incubated for 3 days, then fixed with formalin, stained with crystal violet solution, and plaques were counted. Virus titers were shown as mean value after two independent titrations which were carried out in a duplicate form.

\section{Passage of HmLu and $B H K$ cells infected with various CDV strains}

Sub-confluent cultures of $\mathrm{HmLu}$ or BHK cells were infected with strains Ond, 007Lm, 55L, 009L, M25CR, 011C, 50Con, 50Cbl, Ac96I, Th12, 50Sc, 81ND, 82Con, or $83 \mathrm{mLN}$ of CDV at a multiplicity of infection $(\mathrm{MOI})=1$ in culture bottles. When the cultures became confluent (usually after 3-day incubation) the supernatant media was harvested, centrifuged at 3,000 rpm for $10 \mathrm{~min}$ to remove cell debris, aliquotted, and stored at $-80^{\circ} \mathrm{C}$ until use as cell-free virus. The residual cells were liberated by trypsinization, and one tenth of the liberated cells underwent further cultivation, while the residual nine-tenths were used to liberate the cell-associated virus by freezing at $-80^{\circ} \mathrm{C}$, thawing under flowing water, and centrifugation at 3,000 rpm for $10 \mathrm{~min}$ to remove cell debris. The supernatant fraction was aliquotted and stored at $-80^{\circ} \mathrm{C}$ until use as cell-associated virus. The cycle of passage was repeated, and all cell-free and cell-associated virus samples were titrated on Vero-DST cells.

\section{Results \\ Propagation of CDV strains in $\mathrm{HmLu}$ and $\mathrm{BHK}$ cells}

To find out whether the hamster cell lines can propagate CDV, a study was started with HmLu cells and CDV strains of Ond and 007Lm (Asia 2 group). When the HmLu cells were infected with the Ond strain at a MOI $=1$, the virus induced the cytopathic effect (CPE) of giant cell formation, almost throughout the entire culture within 3-days. The obtained titers of cell-free and cell-associated viruses were 1.3 and $0.6 \times 10^{6} \mathrm{PFU} / \mathrm{ml}$, respectively, at the $1^{\text {st }}$ passage. The passage of infected cells resulted in a low cell density and low virus titer, as shown in Fig. 1 . The cellassociated virus titer obtained from HmLu cells infected with the $007 \mathrm{Lm}$ strain was $2 \times 10^{2} \mathrm{PFU} / \mathrm{ml}$ at the $1^{\text {st }}$ passage. The cell-free virus showed a titer that was about 10 fold lower $\left(1.5 \times 10^{1} \mathrm{PFU} / \mathrm{ml}\right)$ than that of the cell-associ-

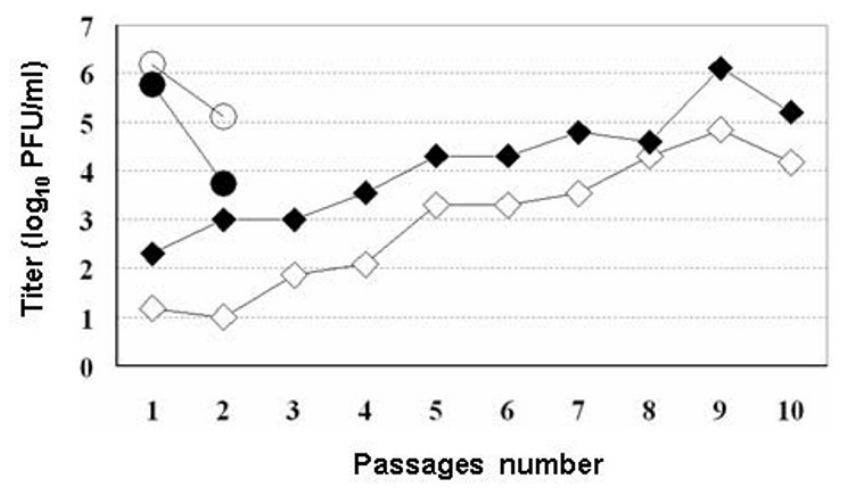

Figure I

Growth profiles of CDV strains of Ond and 007Lm in HmLu cells. Viruses were harvested at every passage as cell-free viruses of Ondestepoort (open circle), or 007Lm (open diamond) and cell-associated viruses of Ondestepoort (black circle), or 007Lm (black diamond) and were titrated on Vero-DST cells as described in Materials and Methods. The obtained virus titers (PFU/ml) were plotted against passages number. 
ated. The cell-free and cell-associated titers increased gradually up to the $9^{\text {th }}$ passage, and the highest virus titer (1.3 $\times 10^{6} \mathrm{PFU} / \mathrm{ml}$ ) was found for the cell-associated virus obtained at the $9^{\text {th }}$ passage. This score is comparable with that obtained for HmLu cells infected with the Ond strain. The persistent infection lasted during passages, although the CPE of giant cell formation appeared and increased gradually after the $4^{\text {th }}$ passage. The infected culture could be transferred up to the $15^{\text {th }}$ passage. On the other hand, the BHK cells infected with strain 007Lm were revealed to be transferred up to the $6^{\text {th }}$ passage (data not shown). According to these results, seven passages for infected $\mathrm{HmLu}$ and five passages for infected BHK cultures were preset for testing residual $12 \mathrm{CDV}$ strains.

As shown in Table 1, all strains of Asia 2 group could grow in both HmLu and BHK cells. Among the strains of Asia 1 group, Ac96I could not grow in either HmLu or BHK cells and Th12 grew in BHK cells but not in HmLu cells. Moreover, strains 50Sc, 81ND, 82Con, and $83 \mathrm{mLN}$ could grow in either $\mathrm{HmLu}$ or BHK cells. The cultures of BHK cells infected with strains 50Cb1, Th12, or 81ND could not be transferred over 3 passages, the cultures of both $\mathrm{HmLu}$ and BHK cells infected with strain 82Con could not be transferred over 4 passages, and the cultures of HmLu cells infected with strains 55L, 009L, 50Sc, 81ND, and $83 \mathrm{mLN}$ also could not be transferred over 7 passages because the massive detachment of giant cells occurred, resulting in a low cell density with extensive appearance of CPE. A typical observation was that strain Th12 grew in BHK cells in a very short period of 3 passages but not in HmLu cells.

\section{Characterization of the CPE induced in hamster cells infected with CDV isolates}

The culture of HmLu cells infected with strain 007Lm showed no CPE by the $3^{\text {rd }}$ passage as if strain $007 \mathrm{Lm}$ induced persistent infection. However, the culture showed CPE of giant cell formation (Fig. 2A) after the $4^{\text {th }}$ passage, and the population of giant cells increased gradually with increasing numbers of passages as the giant cells detached from the substrate as floating giant cells. This giant cell formation did not proceed to the formation of typical syncytia of fusion plaques that were observed in infection of Vero-DST cells with strain $007 \mathrm{Lm}$ by the $15^{\text {th }}$ passage although the population of giant cells increased. At the final stage, the culture showed extensive spread of giant cell formation and floating giant cells (round cells) throughout the entire culture (Fig. 2B). With regard to the infected BHK culture, similar process of CPE development was observed (Fig. 2A and 2B). To characterize giant cell formation, the culture of $\mathrm{HmLu}$ cells infected with strain $007 \mathrm{Lm}$ was liberated by trypsinization at the $8^{\text {th }}$ passage and plated into dishes to form colonies.

The dishes were incubated for 7 days. Colonies of various sizes and morphologies were obtained and classified into three categories as shown in Fig. 3(A - C). Colonies with normal cell morphology, which represented the majority of colonies, as shown in Fig. 3A, hybrid colonies composed of normal and giant cell morphology are shown in Fig. 3B and 3B' (low incidence), and colonies composed of giant cells are shown in Fig. 3C (low incidence). Among the giant cells, a typical body, which seemed to be a nucle-

Table I: The recovered virus titer from $\mathrm{HmLu}$ and BHK cells after several passages.

\begin{tabular}{|c|c|c|c|c|c|}
\hline \multirow{3}{*}{ Virus } & \multirow{3}{*}{ Strain } & \multicolumn{4}{|c|}{ Titer (PFU/ml) recovered from } \\
\hline & & \multicolumn{2}{|r|}{ HmLu (7P) $)^{a)}$} & \multicolumn{2}{|r|}{ BHK (5P) } \\
\hline & & Cell-free & Cell-associated & Cell-free & Cell-associated \\
\hline & 007Lm & $3.4 \times 10^{3}$ & $6.3 \times 10^{4}$ & $6.0 \times 10^{5}$ & $1.2 \times 10^{6}$ \\
\hline & $55 \mathrm{~L}$ & $2.5 \times 10^{5}$ & $2.2 \times 10^{6}(7 \mathrm{P})^{\mathrm{b})}$ & $1.6 \times 10^{5}$ & $2.4 \times 10^{5}$ \\
\hline & $009 \mathrm{~L}$ & $1.0 \times 10^{5}$ & $\left.9.2 \times 10^{5}(7 \mathrm{P})^{\mathrm{b}}\right)$ & $3.0 \times 10^{5}$ & $4.0 \times 10^{5}$ \\
\hline \multirow[t]{6}{*}{ Asia 2} & M25CR & $2.0 \times 10^{3}$ & $8.0 \times 10^{5}$ & $4.0 \times 10^{5}$ & $2.0 \times 10^{5}$ \\
\hline & OIIC & $5.0 \times 10^{3}$ & $2.0 \times 10^{4}$ & $0.6 \times 10^{5}$ & $1.6 \times 10^{5}$ \\
\hline & 50 Con & $6.0 \times 10^{3}$ & $3.0 \times 10^{4}$ & $2.5 \times 10^{5}$ & $0.5 \times 10^{5}$ \\
\hline & $50 \mathrm{Cbl}$ & $3.0 \times 10^{1}$ & $2.2 \times 10^{2}$ & $1.0 \times 10^{4}$ & $\left.7.0 \times 10^{3}(3 \mathrm{P})^{\mathrm{b}}\right)$ \\
\hline & Ac961 & $<5$ & $\leq 5$ & $<5$ & $<5$ \\
\hline & Th 12 & $<5$ & $<5$ & $1.0 \times 10^{4}$ & $\left.8.0 \times 10^{3}(3 \mathrm{P})^{\mathrm{b}}\right)$ \\
\hline \multirow[t]{4}{*}{ Asia I } & $50 \mathrm{Sc}$. & $1.0 \times 10^{5}$ & $1.9 \times 10^{5}(7 \mathrm{P})^{\mathrm{b})}$ & $1.1 \times 10^{5}$ & $1.9 \times 10^{5}$ \\
\hline & 8IND. & $1.5 \times 10^{4}$ & $\left.2.5 \times 10^{4}(7 \mathrm{P})^{\mathrm{b}}\right)$ & $5.5 \times 10^{3}$ & $\left.1.5 \times 10^{4}(3 \mathrm{P})^{\mathrm{b}}\right)$ \\
\hline & 82 Con & $1.2 \times 10^{6}$ & $\left.1.2 \times 10^{6}(4 \mathrm{P})^{\mathrm{b}}\right)$ & $4.5 \times 10^{5}$ & $\left.5.5 \times 10^{5}(4 \mathrm{P})^{\mathrm{b}}\right)$ \\
\hline & $83 \mathrm{mLN}$ & $2.0 \times 10^{5}$ & $\left.1.0 \times 10^{5}(7 \mathrm{P})^{\mathrm{b}}\right)$ & $1.3 \times 10^{5}$ & $1.5 \times 10^{5}$ \\
\hline
\end{tabular}

a) Preset passage level.

b) Cultures at these passages were unable to be transferred further. 
A
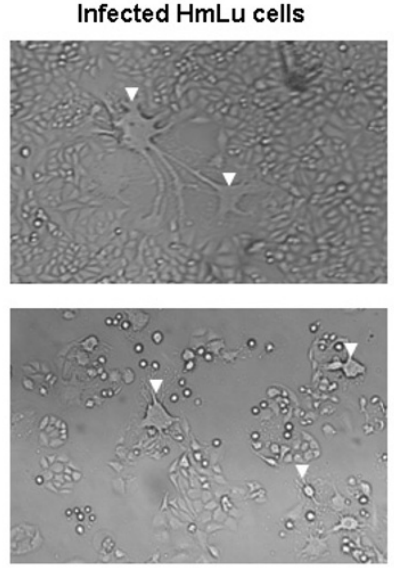
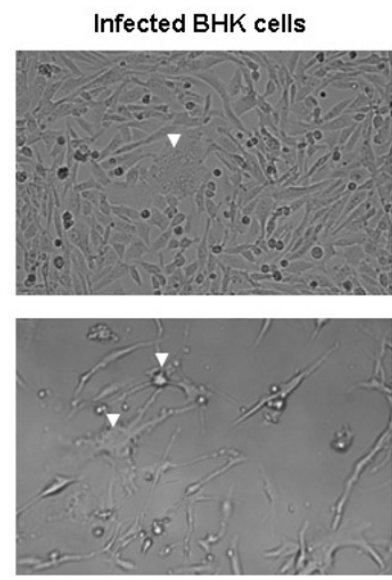

Figure 2

The cytopathic effect (CPE) found in the cultures of $\mathrm{HmLu}$ cells and BHK cells infected with strain 007 Lm. The CPE were indicated by arrows. (A) Infected cultures at the middle stage of infection showing individual CPE among infected cells. (B) Infected cultures at the final stage showing destruction of cell layer and many CPE.

olus, was found as condensed material in the center area surrounded with a suggested nuclear membrane (Fig. 3D; indicated with an arrow). In other giant cells, several condensed materials were found in a circle (Fig. 3E; indicated with arrows).

Strains 55L, 009L, M25CR, 011C, 50Con, 50Cb1, 50Sc, $81 \mathrm{ND}, 82 \mathrm{Con}$, and $83 \mathrm{mLN}$ induced similar CPE of giant
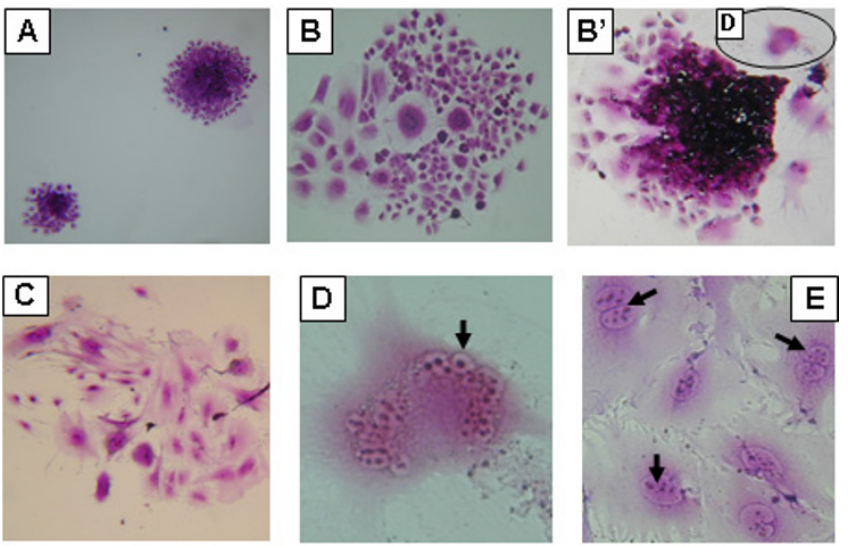

Figure 3

Process of giant cell formation estimated by colony formation. The morphology of colonies of $\mathrm{HmLu}$ cells infected with strain $007 \mathrm{Lm}$ at the $8^{\text {th }}$ passage. Colonies of normal cell shape (A). Hybrid colonies of normal and giant cells $\left(B, B^{\prime}\right)$. A colony composed of giant cells $(C)$. A multinucleated giant cell had several individual nuclei, as indicated by arrow (D) magnified from $D$ in (B'). Giant cells of big nuclei with several condensed materials as indicated by arrows $(E)$. Magnification: 40× (A-C), and 200× (D and E). cell formation in the infected HmLu culture at the middle and late stage of infection except at the first infection. Similar CPE of giant cell formation were also induced in the culture of BHK cells infected with every Asian isolate except for strain Ac96I.

\section{Discussion}

BHK cells had a tendency to propagate field CDV strains more efficiently than HmLu cells as shown in the cases of strains 50Cbl, Th12 and 81ND (Table 1) and strain 007Lm. Fujita et al. [16] reported that BHK cells showed a low susceptibility to recombinant Yanaka virus but showed a high level CDV transcription. This high level CDV transcription might correlate to the rapid destruction of BHK cultures infected with strains 007Lm, 50Cbl, Th12 and $81 \mathrm{ND}$ when compared with the infected cultures of $\mathrm{HmLu}$ cells. However, strain 82Con grew in HmLu cells as rapidly as in BHK cells. Strain Ac96I could not grow in both HmLu and BHK cells and Th12 could grow in BHK cells but not in HmLu cells although it is not known what factor controls the growth of CDV in hamster cells at present. Thus, each virus strain behaved differently against the two hamster cell lines (Table 1). These results indicate that the usage of two hamster cell lines is useful to characterize various field strains by their biological nature.

In this report, all of Asian isolates induced no CPE at the initial stage of infection in the hamster cell lines of both $\mathrm{HmLu}$ and BHK, and this result is coincided with the reports $[11,17]$ that both groups of Asia 1 and Asia 2 showed no CPE in Vero cells at the first infection. However, repeated passage of infected hamster cells resulted in the fact that even Asia 1 isolates except for Ac96I, could grow in hamster cell lines with apparent CPE of giant cell formation. Thus, it is necessary to characterize the infection to a cell line not only at the initial stage but also at the late stage of infection.

The HmLu cells infected with 007Lm had a high passage level of 15 passages, whereas the HmLu cells infected with Ond strain induced massive detachment of giant cells after the $1^{\text {st }}$ passage and were unable to be transferred further. These observations indicated that the development of CPE of giant cell formation in the 007Lm-infected $\mathrm{HmLu}$ cells was very slow. The slow development of CPE enabled the observation of various types of colonies at the $8^{\text {th }}$ passage as shown in Fig. 3. Giant cells seemed to be produced gradually from the infected cells with normal shape by cell fusion. Once giant cells were formed, they had a tendency to detach from the surface of the dish and turn into the floating giant cells.

\section{Conclusion}

This report demonstrated at the first time that the majority of Asian field isolates tested were propagated in hamster 
cell lines of HmLu and BHK. Each virus strain behaved differently against the two cell lines. Since there is no effective method to characterize the field isolates of CDV biologically, the usage of two hamster cell lines can be useful.

\section{Competing interests}

The authors declare that they have no competing interests.

\section{Authors' contributions}

SS performed all experiments in this report under supervisory of KK and KM. N-TL and TU participated in isolation of field strains into Vero-DST cells from the samples of diseased dogs under supervisory of RY. All authors have read and approved the final manuscript.

\section{Acknowledgements}

Serageldeen Sultan received financial support in the form of a PhD degree scholarship from the Egyptian government.

\section{References}

I. Hoff GL, Bigler WJ, Proctor SJ, Stallings LP: Epizootic of canine distemper virus infection among urban raccoons and gray foxes. J Wild Dis 1974, 10:423-428.

2. Carpenter JW, Appel MJG, Erikson RC, Novilla MN: Fatal vaccineinduced canine distemper virus infection in black-footed ferrets. J Am Vet Med Assoc 1976, 169:96I-964.

3. Visser IKG, Kumarev VP, Orvell C, de Vries P, Broeders HWJ, Bildt MWG van de, Greon J, Teppema JS, Burger MC, UytdeHaag FGCM, Osterhaus ADME: Comparison of two morbilliviruses isolated from seals during outbreaks of distemper in North West Europe and Siberia. Arch Virol 1990, I I I:149-164.

4. Appel MJG, Yates RA, Foley GL, Bernstein JJ, Santinelli S, Spelman LH, Miller LD, Arp LH, Anderson M, Barr M, Pearce-Kelling S, Summers BA: Canine distemper epizootic in lions, tigers, and leopards in North America. J Vet Diagn Investig 1994, 6:277-288.

5. Roelke-Parker ME, Munson L, Packer C, Kock R, Cleaveland S, Carpenter M, O'Brien SJ, Pospischil A, Hofmann-Lehmann R, Lutz H, Mwamengele GLM, Mgasa MN, Machange GA, Summers BA, Appel MJG: A canine distemper virus epidemic in Serengeti lions (Panthera leo). Nature 1996, 379:441-445.

6. Haig DA: Canine distemper-immunization with avianized virus. Onderstepoort J Vet Res 1956, 17:149-153.

7. Kai C, Ochikubo F, Okita M, linuma T, Mikami T, Kobune F, Yamanouchi K: Use of B95a cells for isolation of canine distemper virus from clinical cases. J Vet Med Sci 1993, 55: 1067-1070.

8. Lednicky JA, Meehan TP, Kinsel MJ, Dubach J, Hungerford LL, Sarich NA, Witecki KE, Braid MD, Pedrak C, Houde CM: Effective primary isolation of wild-type canine distemper virus in MDCK, MVILu and Vero cells without nucleotide sequence changes within the entire haemagglutinin protein gene and in subgenomic sections of the fusion and phospho protein genes. J Virol Methods 2004, I I 8: I47-I 57.

9. Tatsuo H, Ono N, Yanagi Y: Morbilliviruses use signaling lymophocyte activation molecule $(C D \mid 50)$ as cellular receptors. J Virol 200I, 75:5842-5850.

10. Seki F, Ono N, Yamaguchi R, Yanagi Y: Efficient isolation of wild strains of canine distemper virus in Vero cells expressing canine SLAM (CDI50) and their adaptability to marmoset B95a cells. J Virol 2003, 77:9943-9950.

II. Lan NT, Yamaguchi R, Uchida K, Sugano S, Tateyama S: Growth profiles of recent canine distemper isolates on Vero cells expressing canine signaling lymphocyte activation molecule (SLAM). J Comp Path 2005, 133:77-8I.

12. Lan NT, Yamaguchi R, Inomata A, Furuya Y, Uchida K, Sugano S, Tateyama S: Comparative analyses of canine distemper viral isolates from clinical cases of canine distemper in vaccinated dogs. Vet Microbiol 2006, I I 5:32-42.
13. Kurogi $H$, Inaba $Y$, Takahashi E, Sato K, Omori T, Miura $Y$, Goto $Y$, Fujiwara Y, Hatano Y, Kodama K, Fukuyama S, Sasaki N, Matumoto $\mathrm{M}$ : Epizootic congenital arthrogryposis-hydranencephaly syndrome in cattle: Isolation of akabane virus from affected fetuses. Arch Virol 1976, 5 I:67-74.

14. McPherson I, Stoker M: Polyoma transformation of hamster cell clones an investigation of genetic factors affecting cell competence. Virology 1962, 16:147-151.

15. Sultan S, Charoenvisal N, Lan NT, Yamaguchi R, Maeda K, Kai K: The Asia 2 specific signal peptide region and other domains in fusion protein genes characterized Asia I and Asia 2 canine distemper viruses. Virology Journal 2009, 6:157.

16. Fujita K, Miura R, Yoneda M, Shimizu F, Sato H, Muto Y, Endo Y, Tsukiyama-Kohara K, Kai C: Host range and receptor utilization of canine distemper virus analyzed by recombinant viruses: Involvement of heparin-like molecule in CDV infection. Virology 2007, 359:324-335.

17. Lan NT, Yamaguchi R, Hirai T, Kai K, Morishita K: Relationship between growth behavior in Vero cells and molecular Characteristics of Asia I and Asia 2 groups of recently isolated canine distemper viruses. J Vet Med Sci 2009, 7 I:457-46I.
Publish with Bio Med Central and every scientist can read your work free of charge

"BioMed Central will be the most significant development for disseminating the results of biomedical research in our lifetime. "

Sir Paul Nurse, Cancer Research UK

Your research papers will be:

- available free of charge to the entire biomedical community

- peer reviewed and published immediately upon acceptance

- cited in PubMed and archived on PubMed Central

- yours - you keep the copyright

Submit your manuscript here:

http://www.biomedcentral.com/info/publishing_adv.asp
BioMedcentral 